\title{
Enkephalins Stimulate Leukemia Cell Migration and Surface Expression of CD9
}

Wyrta Heagy, ${ }^{\star \S}$ Karen Duca, ${ }^{*}$ and Robert W. Finberg ${ }^{\star *}$

* Laboratory of Infectious Diseases, Dana-Farber Cancer Institute and ${ }^{\ddagger}$ Departments of Medicine and ${ }^{\S}$ Pathology, Harvard Medical School, Boston, Massachusetts 02115

\begin{abstract}
Opioid peptides have been implicated in the regulation of tumor growth and biology; however, little attention has been given to the mechanisms that are involved. In this study we show that physiological concentrations of the endogenous opioid neuropeptide methionine-enkephalin (MET-ENK)

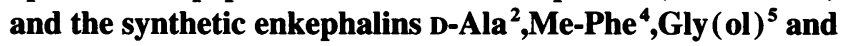
$\mathrm{D}-\mathrm{Ala}^{2}, \mathrm{D}-\mathrm{Leu}^{5}$ are stimulants for the in vitro migration of pre-B acute lymphoblastoid leukemia (ALL) cells. Activation of the human pre-B ALL cell lines NALM 6 and LAZ 221 with MET-ENK resulted in both an increase in their migration and an augmentation in the surface expression of the leukemia cell marker CD9. The opiate receptor antagonist naloxone reversed these enkephalin-induced effects on the leukemia cells. When the pre-B ALL cells were preincubated with an anti-CD9 $\mathrm{mAb}$ before challenge with METENK their migration to the enkephalin was markedly reduced. These studies show that endogenous and synthetic opioid peptides are stimulants for pre-B ALL cell migration and suggest that CD9 is important in the regulation of leukemia cell motility. (J. Clin. Invest. 1995. 96:1366-1374.) Key words: enkephalins $\bullet$ opioid peptides $\bullet$ cell movement $\bullet$ pre$\mathrm{B}$ cell $\cdot$ leukemia leukocyte-adhesion receptors
\end{abstract}

\section{Introduction}

First identified in brain tissues for their analgesic activity the opioid family of neuropeptides are now recognized as pleiotropic hormones that modulate vital processes in the periphery as well as the CNS. These neuropeptides are important in the regulation of moods, behaviors, higher cognitive processes, reproduction, pain control, inflammatory responses, and a variety of immune functions (1-5). In humans the intravenous use of opioid alkaloids has been associated with an increased risk for infectious and oncogenic diseases (6). Evidence obtained in animal models has documented that use of opioid peptides or alkaloids diminishes resistance to infection (6-8). Studies showing that stress stimulates the endogenous synthesis and release of opioid peptides has fueled speculation that the stress induced-release of these agents is important in disease processes

Address correspondence to Wyrta Heagy, Endocrinology Office, Medical Specialty Center-D3, Minneapolis Medical Research Foundation, 914 South Eighth Street, Minneapolis, MN 55404. Phone: 612-3477629; FAX: 612-337-7372.

Received for publication 17 February 1994 and accepted in revised form I June 1995.

J. Clin. Invest.

(C) The American Society for Clinical Investigation, Inc.

0021-9738/95/09/1366/09 \$2.00

Volume 96, September 1995, 1366-1374
$(1,3)$. Within the past decade many reports have detailed the in vitro effects of opioid peptides on human and rodent immunocytes; however, the precise mechanism(s) by which these neuropeptides influence health or disease have not been defined.

The best studied activity of opioid peptides is their characteristic effect on pain. This morphomimetic activity is dependent on the $\mathrm{NH}_{2}$ terminal sequence (Tyr-Gly-Gly-Phe-Met or Leu) of the analgesic peptides and is blocked by classical opiate receptor antagonists such as naloxone (4). Opioid peptides interact with a number of distinct opiate/opioid receptor types (e.g., $\delta, \mu, \kappa)$ and subtypes (e.g., $\mu 1, \mu 2, \delta 1, \delta 1, \kappa 1, \kappa 2$ ) that are expressed in the CNS and periphery $(3,4,9,10)$. Peripheral blood leukocytes have been reported to express both classical (naloxone-sensitive) and nonclassical (naloxone-insensitive) opiate/opioid recognition sites $(3,9)$.

Opioid peptides are potent signals that direct leukocyte motility and one of their key functions in the periphery may be in leukocyte recruitment and migration (11). Studies in rodent and large animal models have shown that the opioid pentapeptide methionine-enkephalin (MET-ENK) ${ }^{1}$ enhances lymphocyte trafficking $(7,11-13)$, stimulates transendothelial migrations, and causes the redistribution of circulating leukocytes $(14,15)$. In sheep the infusion of MET-ENK into the afferent lymphatics of popliteal nodes caused lymphocyte migrations from the node into the efferent lymph (16). When MET-ENK was injected into the cerebral ventricles of rodents both lymphocytes and macrophages were recruited to the injection site (14). Other studies carried out in vitro have confirmed that MET-ENK is chemotactic for isolated human peripheral blood T cells (11), monocytes $(13,14)$, and polymorphonuclear leukocytes (17). Opioid peptides, like other leukocyte chemoattractants, have been shown to trigger a number of biochemical and cellular events including transmembrane signaling (18), cell flattening, membrane spreading, and pseudopod extension (19). Despite this impressive number of studies documenting the effects of MET-ENK on leukocyte motility there is little known concerning the molecular processes that regulate the enkephalin-mediated effects.

MET-ENK and other opioid peptides have been reported to bind to certain kinds of tumor cells and to have antiproliferative activity (20). It is known that many growth-modulating factors also regulate cell movement (21-24); however, the effect of opioid peptides on the motility of leukemias, transformed leukocytes or other type tumors has not been addressed. To gain a better understanding of the actions of opioid peptides we have studied the effects of MET-ENK and other enkephalins on two human pre-B acute lymphoblastoid leukemia (ALL) cell lines, NALM 6 and LAZ 221, and the EBV-transformed mature B

1. Abbreviations used in this paper: ALL, acute lymphoblastoid leukemia; DADLE, [D-Ala, ${ }^{2} \mathrm{D}-\mathrm{Leu}^{5}$ ]-enkephalin; DAMGO, [D-Ala, ${ }^{2} \mathrm{Me}-$ Phe, ${ }^{4} \mathrm{Gly}(\mathrm{ol})^{5}$ ]-enkephalin; DesTyr-LEU-ENK, H-Gly-Gly-Phe-Leu$\mathrm{OH}$; MET-ENK, methionine-enkephalin. 
cell line LAZ 388. We have used a migration assay and monitored cell morphology (i.e., cell flattening and membrane spreading) using flow cytometric analysis of forward and right angle light scatter for assessing the effects of MET-ENK and other opiate receptor ligands. Previously, other investigators have shown that chemotactic factors modulate the expression and function of cell surface adhesion molecules (e.g., the $\beta_{1}$ and $\beta_{2}$ integrins) (22-24). Since MET-ENK has been shown to be a stimulus for lymphocyte migration (11) we have investigated the possibility that this enkephalin also modulates the expression of adhesion receptors. For this purpose we used immunofluorescent staining and flow cytometry to measure the effects of MET-ENK on the surface expression of a panel of B cell determinants.

In this report we show that MET-ENK and synthetic enkephalin analogs serve as potent signals for the migration of NALM 6 and LAZ 221 pre-B ALL cells. Exposure of these leukemia cells to MET-ENK results in a discrete and transient increase in CD9 surface expression as well as an enhancement in migration. Preincubation of the leukemia cells with anti-CD9 mAb before challenge with MET-ENK blocks their migration to the enkephalin. These findings suggest that leukemia cell migration to MET-ENK is regulated, at least in part, via CD9 expression. In previous reports CD9 has been implicated in the formation of pre-B ALL cell homotypic aggregations $(25,26)$ and in the spontaneous locomotion of some kinds of tumor cells $(27,28)$. Our findings provide the first evidence that CD9 is involved in the migration of lymphoid cells. These studies provide new insights into the actions of opioid peptides and into mechanisms that regulate lymphoid cell motility.

\section{Methods}

Cells. The pre-B ALL cell lines NALM 6 and $\mathrm{LAZ}_{221}\left(\mathrm{CD}^{+}, \mathrm{CD} 0^{+}\right.$, $\left.\mathrm{sIg}^{-}\right)$and the EBV-transformed B lymphoblastoid cell line LAZ 388 $\left(\mathrm{CD} 19^{+}, \mathrm{CD} 20^{+}, \mathrm{CD}^{-1}, \mathrm{CD}^{-} 0^{-}\right)$have been described previously (29). The LAZ 221 and LAZ 388 lines were established from donor cells harvested from a patient at the Dana-Farber Cancer Institute, Boston, MA (29) and were obtained for these studies from Dr. Jerome Ritz. Cells were passaged $\left(1-2 \times 10^{5} / \mathrm{ml}\right)$ every $2-4 \mathrm{~d}$ in RPMI 1640 medium (BioWhittaker, Inc., Walkersville, MD) supplemented with $2 \mathrm{mM}$ glutamine, a solution of $100 \mathrm{U} / \mathrm{ml}-100 \mu \mathrm{g} / \mathrm{ml}$ of penicillinstreptomycin (Gibco Laboratories, Grand Island, NY), and $10 \%$ bovine serum (Hyclone Laboratories, Inc., Logan, UT). Cultures were maintained at $37^{\circ} \mathrm{C}$ in a $5 \% \mathrm{CO}_{2}$ tissue culture incubator.

Reagents and antibodies. The naturally occurring pentapeptide MET-ENK (Tyr-Gly-Gly-Phe-Met), and the synthetic peptides [D-

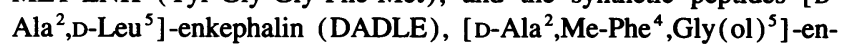
kephalin (DAMGO), H-Gly-Gly-Phe-Leu-OH (DesTyr-LEU-ENK), and FMLP were purchased from Sigma Chemical Co. (St. Louis, MO). Naloxone (Narcan) was obtained from DuPont Pharmaceuticals (Manati, Puerto Rico).

Anti-CD9 and -CD10 mAb of the IgG1 isotype were from Biodesign International (Kennebunkport, ME) and those of the IgG2a isotype were obtained from Amac, Inc. (Westbrook, ME). Anti-CD20 (IgG1), $-\mathrm{CD} 14$ (IgG2a), -CD29 (IgG1) and -CD54 (IgG1) mAb were from Biodesign International. Anti-CD72 (IgG2a), and -CD23 (IgGl) mAb were from The Binding Site, Inc., (Birmingham, United Kingdom) and anti-CD22 (IgG1) was from Amac Inc., Anti-CD2 (IgG1), -CD3 (IgG2a), -CD11a (IgG1), -CD11b (IgG1), -CD18 (IgG1), -CD45 (IgG2a), -CD58 (IgG1), -Class I (HLA-A,B,C; IgG2a), and -Class II (HLA-DR; IgG2b) were prepared as ascites developed in Balb/c mice. Hybridoma cells were obtained for the anti-Class II mAb (LB3.1) from Dr. Peter Knudsen and Dr. Jack Strominger, Dana-Farber Cancer Insti- tute, Boston, MA and for anti-CD2 (HB195), -CD3 (CRL 8001), CD11a (HB 202), -CD11b (HB204), -CD18 (HB203), -CD45 (HB196), -CD58 (HB205) and -Class I (HB 95) from the American Type Culture Collection (Rockville, MD). Anti-CD19 mAb (IgG1) was a gift from Dr. Ken Anderson, Dana-Farber Cancer Institute, Boston, MA. The mAb recognizing VLA's 1-6 were from the V Human Leukocyte Typing Workshop (subpanel 6) and the DE9N anti-VLA $\beta$ chain mAb (IgG1) was provided by Dr. Jeff Bergelson, Dana-Farber Cancer Institute, Boston, MA (30). The MOPC 21 myeloma protein (IgG1) that was used as a control was purchased from Organon Teknika Cappel (Durham, NC).

Migration assays. Cell migration was measured using microchemotaxis chambers (NeuroProbe, Inc., Cabin John, MD) as previously described (11). Cells $\left(5 \times 10^{6} / \mathrm{ml}\right)$ were separated from peptides in the lower wells of the chamber by nitrocellulose filters (Sartorious, $5 \mu \mathrm{m}$ pore; Neuroprobe, Inc.). In some studies the cells were preincubated with $10^{-5} \mathrm{M}$ naloxone for $15 \mathrm{~h}$ at $37^{\circ} \mathrm{C}$ or anti-CD9, -CD10, or -VLA $4 \mathrm{mAb}$ for $30 \mathrm{~min}$ at $4^{\circ} \mathrm{C}$ and then incubated in the microchemotaxis chambers for $75-90 \mathrm{~min}$ at $37^{\circ} \mathrm{C}$. The nitrocellulose filters were fixed and stained with Congo red dye (Sigma Chemical Co.). Cells within the filters were identified by fluorescence microscopy and then enumerated utilizing an optical image analyzer (Optomax $\mathrm{V}$ image analyzing system; Analytical Instruments, Hollis, NH). In some studies the cells were identified visually and photographed with the use of a fluorescence microscope.

Forward and right angle light scatter analysis of the morphological response to MET-ENK. The effects of MET-ENK on cell morphology were measured using flow cytometric analysis of forward and right angle light scatter as previously described (31). For these studies $10^{6}$ cells were incubated for $5 \mathrm{~min}$ at $37^{\circ} \mathrm{C}$ in a $1-\mathrm{ml}$ vol of PBS, alone or PBS containing MET-ENK. Some samples were preincubated for 15 min on ice in PBS containing $10^{-5} \mathrm{M}$ naloxone. Samples were analyzed using a FACScan ${ }^{\oplus}$ flow cytometer with excitation at $488 \mathrm{~nm}$ (Becton Dickinson and Co., Mountain View, CA) (31). Histograms were obtained from the analysis of 10,000 cells and data were analyzed using the Lysys System software package (Becton Dickinson and Co.). Fluorescence was measured as the arithmetic/linear mean relative fluorescence intensity; the range of values was between 1 and 10,000 $\left(10^{0}-10^{4}\right)$.

Immunofluorescence staining and flow cytometric analysis of cell surface molecules. Cells were resuspended at $10^{6} / \mathrm{ml}$ in PBS and then incubated for periods of $5-120 \mathrm{~min}$ at $37^{\circ} \mathrm{C}$ with MET-ENK $\left(0-10^{-5}\right.$ $M$, final concentration). Incubations were terminated by transferring the samples to an ice bath and then pelleting the cells by centrifugation at $1,800 \mathrm{rpm}$ for $5 \mathrm{~min}$ at $4^{\circ} \mathrm{C}$.

Immunofluorescence staining was carried out in 4-ml tubes maintained in an ice water bath. Cells $\left(10^{6}\right)$ in $100-\mu 1$ vol of PBS were incubated with the primary antibody for $30 \mathrm{~min}$, washed, and then stained by a second incubation with affinity isolated, human absorbed, FITC conjugated goat $\mathrm{F}\left(\mathrm{ab}^{\prime}\right) 2$ anti-mouse Ig (Tago Inc., Burlingame, CA). Cells were fixed in a $2 \%$ solution of formalin and maintained in the dark at $10^{\circ} \mathrm{C}$ until analyzed.

Flow cytometric analysis was performed using a FACScan ${ }^{\oplus}$ Flow Cytometer (Becton Dickinson and Co.) equipped with a HP9000 Series computer. Data were collected as histograms depicting the fluorescence intensity for 5,000-10,000 cells per sample; arithmatic/linear mean relative fluorescence intensities were obtained using the Lysys System software analysis package. Arithmatic/linear values (range, 1-10,000) were used for all sample to sample comparisons. The nonbinding IgG1 MOPC myeloma protein as well as isotype matched nonreactive mAb were used as controls for measuring the autofluorescence of B cells.

\section{Results}

Methionine-enkephalin stimulates a naloxone-sensitive alteration in the morphology of NALM 6 cells. An initial set of studies were carried out to determine whether cultured human 

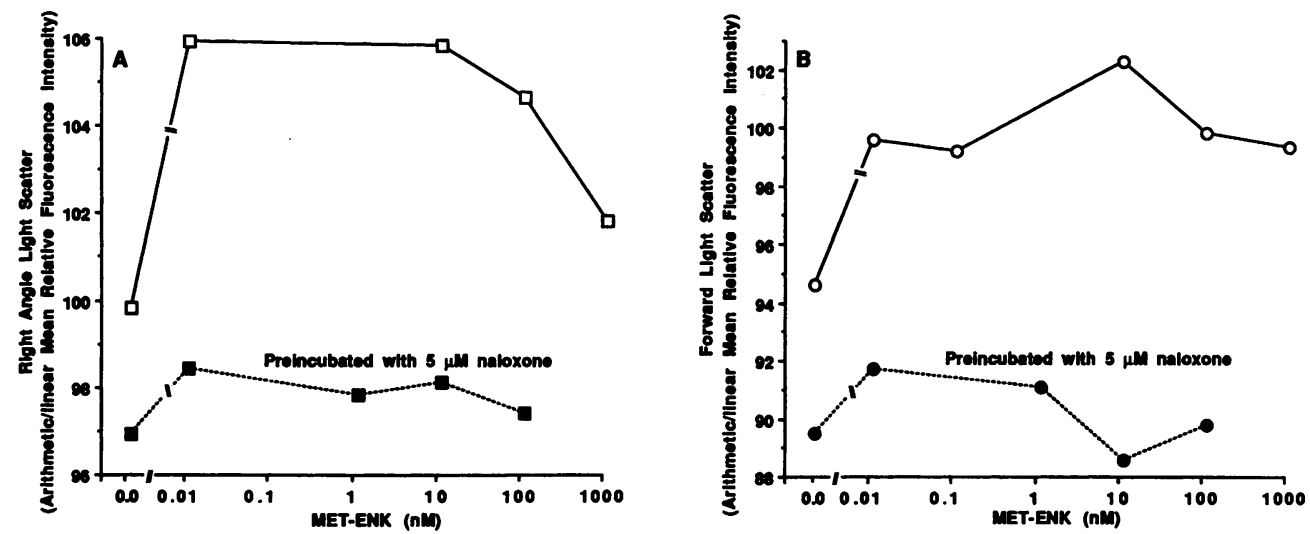

Figure 1. Methionine-enkephalin induces a morphological change in NALM 6 cells. NALM 6 cells $\left(10^{6} / \mathrm{ml}\right)$ were preincubated in PBS alone or containing $10^{-5} \mathrm{M}$ naloxone for $15 \mathrm{~min}$ on ice, stimulated with the indicated concentrations of MET-ENK, and then incubated for an additional $5 \mathrm{~min}$ at $37^{\circ} \mathrm{C}$. Analysis of forward and right angle light scatter was performed using a Becton Dickinson FACScan ${ }^{\circledR}$ flow cytometer as described in Methods. Histograms of light scatter were obtained by analyzing 10,000 cells per sample.

Data are expressed as the arithmetic/linear mean fluorescence intensity (y-axis) versus concentration of MET-ENK (x-axis). ( $A$ ) Right angle light scatter for samples preincubated in PBS alone ( $\square-\square)$ or PBS with $10^{-5} \mathrm{M}$ naloxone ( $\left.-\square\right)$. $(B)$ forward light scatter from samples preincubated in PBS alone (O-O) or PBS with $10^{-5} \mathrm{M}$ naloxone $(\bullet-\bullet)$.

B cells responded to the naturally occurring opioid pentapeptide MET-ENK. Flow cytometric analysis of forward and right angle light scatter was used for monitoring the effects of MET-ENK on the morphology of NALM 6 cells. As indicated (Fig. 1), treatment of the NALM 6 cells with MET-ENK provoked a rapid change in cell morphology (i.e., an increase in right angle and forward light scatter). Physiological doses (i.e., $\leq 0.1 \mathrm{nM}$ ) of MET-ENK initiated this morphological response since enkephalin doses as low as $0.01 \mathrm{nM}$ elicited a near maximum response (Fig. 1). These results provided evidence that the NALM 6 pre-B ALL cell line was responsive to MET-ENK. Consistent with the specificity expected for a classical opiate/ opioid effect the morphological response to MET-ENK was inhibited when the NALM 6 cells were preincubated with the opiate receptor antagonist naloxone (Fig. 1). Whereas the application of MET-ENK to the NALM 6 cells enhanced both right angle and forward light scatter the preincubation in naloxone, alone caused a modest negative deflection in the baseline (Fig. 1).

CD9 expression on pre-B acute lymphoblastoid leukemia cells is modulated by methionine-enkephalin. Our studies showing that MET-ENK provoked physical changes in the NALM 6 cell membrane (Fig. 1) prompted us to investigate the possibility that this enkephalin also induced a rearrangement in membrane proteins. As indicated, (Figs. 2 and 3 and Table I) a panel of $\mathrm{mAb}$ was used to assess the effects of MET-ENK on the expression of $B$ cell surface determinants; samples of NALM 6, LAZ 221, and LAZ 388 cells were incubated with and without the enkephalin and the expression of surface markers measured with the use of immunofluorescent staining and flow cytometry. The incubation of NALM 6 or LAZ 221 cells with MET-ENK resulted in a transient increase in their expression of CD9 (Figs. 2 and 3). A brief incubation of the pre-B ALL cells with MET-ENK (i.e., $\leq 10 \mathrm{~min}$ ) was sufficient to cause the enhancement in CD9 expression (Fig. $3 \mathrm{~A}$ ). This enhanced level of CD9 expression was sustained for periods of $60 \mathrm{~min}$ but declined to near baseline by $120 \mathrm{~min}$ (Fig. $3 \mathrm{~A}$ ). The induction of CD9 surface molecules by MET-ENK was dose dependent (Fig. 3 B). CD9 expression was increased, albeit modestly, by the low MET-ENK dose of $0.01 \mathrm{nM}$, further increased with the greater $100 \mathrm{nM}$ dose, and still further increased, with the maximum dose $(10,000 \mathrm{nM})$ (Fig. $3 \mathrm{~B})$. Whereas MET-ENK caused an augmentation in the CD9 molecules displayed on the surfaces of pre-B ALL cells the enkephalin had no effect on their expression of CD10 (Figs. 2 and $3 A$ ). These findings show that the MET-ENK-stimulated enhancement in CD9 expression is specific and not solely the result of an enkephalinmediated increase in cell surface area.

When the pre-B ALL cells were incubated in a mixture of MET-ENK and a 100-fold excess of naloxone the induction of CD9 by MET-ENK was totally blocked indicating the specificity of the enkephalin response (Fig. $3 \mathrm{C}$ ).

Immunofluorescent staining for other adhesion molecules

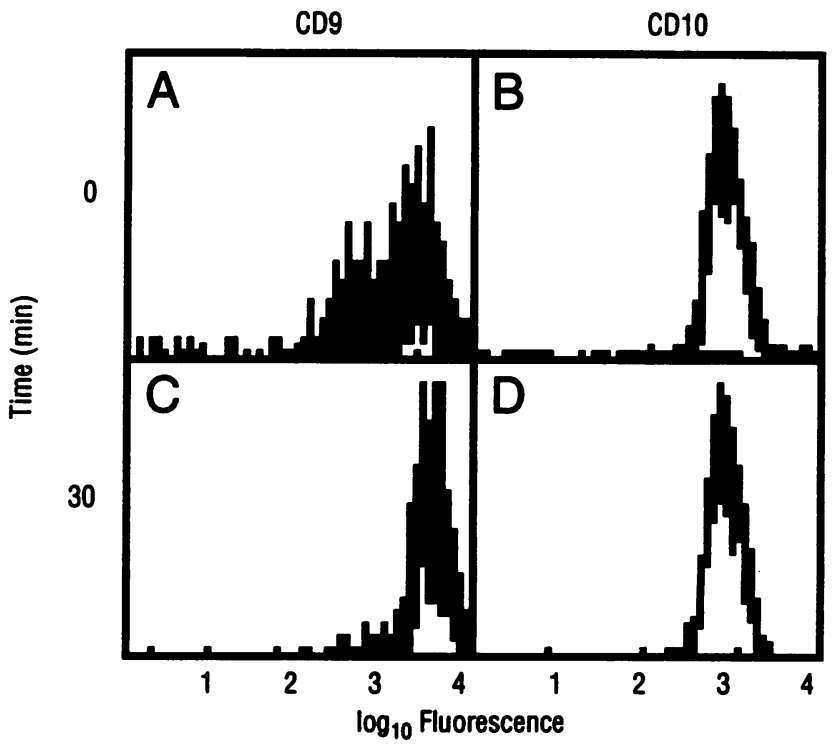

Figure 2. Methionine-enkephalin causes a discrete, transient up-regulation in the CD9 molecules expressed on the surface of NALM 6 cells. NALM 6 cells $\left(10^{6} / \mathrm{ml}\right)$ were incubated at $37^{\circ} \mathrm{C}$ with MET-ENK $\left(10^{-7}\right.$ $M)$ for $0(A$ and $B)$ or $30 \mathrm{~min}(C$ and $D)$. Cells were then transferred to an ice bath, pelleted by centrifugation, and stained as described in Methods. Data are shown as histograms depicting the distribution of 10,000 cells labeled with anti-CD9 ( $A$ and $C$ ) or CD-10 ( $B$ and $D$ ) $\mathrm{mAb}$. The anti-CD9 and anti-CD10 mAb used for these experiments were isotype matched (IgG1). 

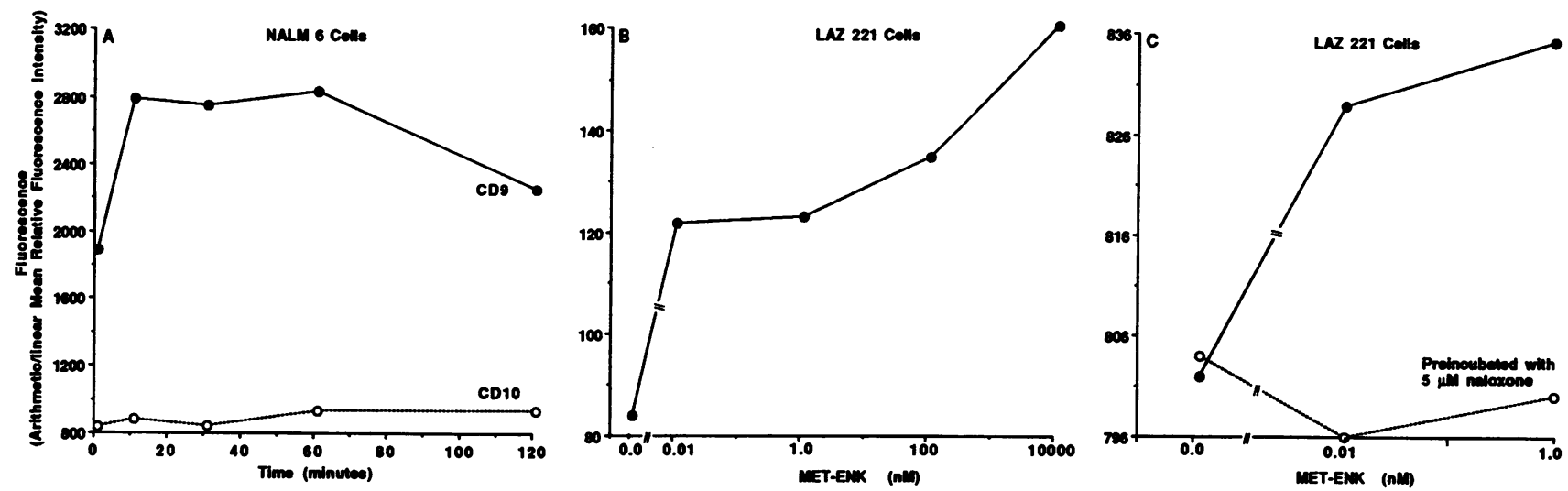

Figure 3. Methionine-enkephalin causes a rapid and dose-dependent increase in the CD9 but not CD10 molecules expressed on pre-B leukemic cells. Data are presented as the arithmetic/linear mean relative fluorescence intensities measured for 10,000 cells labeled with anti-CD9 or CD10 mAb. Cell samples were prepared and stained for immunofluorescent analysis as described for Fig. 2 and in Methods. In panel $A$, NALM 6 cells were incubated with MET-ENK $\left(10^{-7} \mathrm{M}\right)$ for the times indicated. In panel $B$, LAZ 221 cells were incubated with MET-ENK at the doses indicated for $5 \mathrm{~min}$ at $37^{\circ} \mathrm{C}$. In panel $C$, LAZ 221 cells were incubated at $37^{\circ} \mathrm{C}$ for $15 \mathrm{~min}$ with MET-ENK $\left(10^{-7} \mathrm{M}\right)(\bullet-\bullet)$ or with both MET-ENK and naloxone $\left(10^{-5} \mathrm{M}\right)(\mathrm{O}-\mathrm{O})$. The anti-CD9 and anti-CD10 mAb used for these experiments were of the IgG2a isotype.

Table I. Methionine-Enkephalin Effects on the Surface Expression of Lymphocyte Determinants

\begin{tabular}{|c|c|c|c|c|c|c|c|}
\hline \multirow[b]{3}{*}{ Cell determinant } & \multirow{3}{*}{$\begin{array}{c}\text { Antibody } \\
\text { isotype }\end{array}$} & \multicolumn{6}{|c|}{ Fluorescence* } \\
\hline & & \multicolumn{2}{|c|}{ NALM 6} & \multicolumn{2}{|c|}{ LAZ 221} & \multicolumn{2}{|c|}{ LAZ 388} \\
\hline & & $(-)$ & $(+)^{\ddagger}$ & $(-)$ & $(+)$ & $(-)$ & $(+)$ \\
\hline CD 9 & IgG1 & 140.8 & 400.0 & 107.1 & 220.5 & 4.2 & 4.0 \\
\hline CD 10 & IgG1 & 37.1 & 37.0 & 11.0 & 10.2 & 0.93 & 1.0 \\
\hline Class II (HLA-DR) & IgG1 & 14.0 & 14.8 & 41.9 & 43.0 & 29.0 & 30.0 \\
\hline Class I (HLA-A,B,C) & IgG1 & 225.9 & 227.0 & 156.7 & 157.4 & 29.9 & 31.2 \\
\hline CD11a (LFA1 $\alpha)$ & IgG1 & $\mathrm{ND}^{3}$ & ND & 1.0 & 1.1 & 12.4 & 11.4 \\
\hline CD11b (Mac 1) & IgG1 & 1.0 & 1.1 & 1.4 & 1.5 & 1.5 & 1.5 \\
\hline CD18 (Integrin $\beta$ chain) & IgG1 & 1.1 & 1.4 & 1.0 & 1.1 & 11.9 & 10.1 \\
\hline CD54 (ICAM-1) & IgG1 & 9.3 & 10.5 & 1.5 & 1.5 & 18.7 & 16.6 \\
\hline CD44 (homing receptor) & IgG1 & 1.0 & 2.2 & ND & ND & 79.0 & 84.6 \\
\hline CD19 & IgG1 & ND & ND & 1.7 & 1.9 & 8.6 & 8.0 \\
\hline CD58 (LFA-3) & IgG1 & 1.0 & 0.9 & 1.7 & 1.9 & 22.4 & 21.8 \\
\hline $\mathrm{CD} 22$ & IgG1 & 2.3 & 3.1 & ND & ND & 11.4 & 11.1 \\
\hline CD20 & IgG1 & 1.5 & 1.3 & 1.0 & 1.1 & 1.7 & 1.7 \\
\hline CD72 & IgG2a & 1.6 & 2.8 & ND & ND & 1.4 & 1.7 \\
\hline CD29 (VLA- $\beta$ chain) & IgG1 & 8.4 & 9.3 & 1.7 & 1.9 & 11.4 & 11.2 \\
\hline VLA- $\beta$ chain; DE9N" & IgG1 & 13.6 & 13.8 & 5.8 & 5.6 & 11.5 & 11.1 \\
\hline VLA-1 & IgG1 & 1.1 & 0.6 & ND & ND & 1.8 & 2.0 \\
\hline VLA-3 & IgG & 1.1 & 0.7 & ND & ND & 1.0 & 1.0 \\
\hline VLA-5 & IgG1 & 5.2 & 4.9 & ND & ND & 1.0 & 1.0 \\
\hline CD $49 b$ (VLA- $\alpha 2$ chain) & IgG1 & 1.0 & 0.9 & ND & ND & 1.0 & 1.0 \\
\hline CD49f (VLA- $\alpha 6$ chain) & IgG1 & 1.8 & 1.3 & ND & ND & ND & ND \\
\hline CD49d (VLA- $\alpha 4$ chain) & IgG1 & 3.9 & 4.4 & ND & ND & ND & ND \\
\hline $\mathrm{CD} 23$ & IgG1 & 1.8 & 1.6 & ND & ND & 68.2 & 70.7 \\
\hline CD45 (T200) & $\operatorname{IgG} 2 a$ & 1.1 & 1.0 & ND & ND & 27.4 & 27.3 \\
\hline
\end{tabular}

* Cells were labeled for analysis as described for Figs. 2 and 3 and in Methods. Fluorescence values were measured from histograms collected for samples of 5,000 or 10,000 cells. Data are expressed as ratios: [(arithmetic-linear mean relative fluorescence intensity measured for indicated $\mathrm{mAb})] /$ [(arithmetic-linear mean relative fluorescence intensity measured for isotype matched control)]. ${ }^{\ddagger}$ Cells were incubated for $30 \mathrm{~min}$ at $37^{\circ} \mathrm{C}$ in PBS alone (-) or PBS containing $10^{-7}$ M MET-ENK (+). ${ }^{8} \mathrm{ND}=$ not done. " Two anti-VLA- $\beta 1$ (CD29) mAb were used for these studies; the data obtained for these mAb are listed for anti-CD29 (VLA- $\beta$ chain) and VLA- $\beta$;DE9N. 

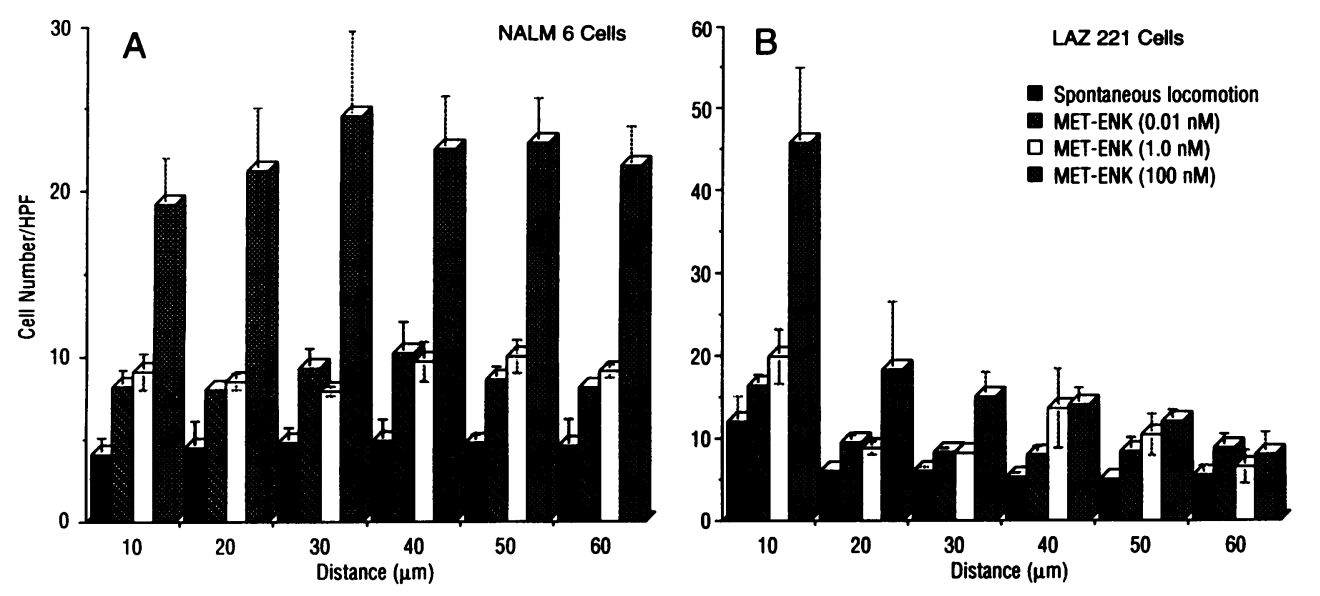

Figure 4. NALM 6 and LAZ 221 cells migrate to the opioid pentapeptide methionine-enkephalin. MET-ENK was prepared in the assay buffer consisting of Dulbecco's modified PBS and $0.1 \%$ chick egg albumin and then added in 35$\mu$ l volumes to the lower wells of the chemotaxis chamber. A Sartorius (5- $\mu \mathrm{m}$ pore) nitrocellulose filter was placed between the upper and lower reservoirs and the cells $\left(5 \times 10^{6} / \mathrm{ml}\right)$ were then added to the upper wells in $60-\mu \mathrm{l}$ portions of the assay buffer. After a 90 -min incubation at $37^{\circ} \mathrm{C}$ the filters were removed, fixed, and

stained with Congo red dye as previously described (11). Cells which migrated into the filter were enumerated utilizing fluorescence microscopy and an Optimax V image analyzing system. 10 high power fields (HPF) were measured at 10- $\mu \mathrm{m}$ distances through the filter. Data are presented as the means \pm SD for 30 values (i.e., 10 readings $\times$ triplicate assays). Note: the scales for the $y$-axis are different in panels $A$ and $B$.

including VLA 4 (CD49d) or -5 ( $\beta$-1 integrins) and the common VLA $\beta 1$ chain (CD29) was equivalent on NALM 6 cell samples incubated with $(+)$ or without $(-)$ MET-ENK (Table I). With the pre-B ALL cells the fluorescence intensity measured for other $\beta-1$ integrins (VLA-1, VLA-3, CD49b, or CD49f) or for $\beta-2$ integrins (CD11a, CD11b, and CD18) was near that of the IgG1 isotype control (i.e., between 1 and 1.5 times the control value) regardless of whether the cells were incubated with $(+)$ or without $(-)$ MET-ENK (Table I).

As expected, immunofluorescent staining of the LAZ 388 cells revealed a phenotype distinct from that of the pre-B ALL lines and characteristic of mature EBV-transformed B cells (Table I). With the LAZ 388 cells the level of cell surface staining for CD9 and the $\beta-1$ and $\beta-2$ integrins as well as other determinants was equivalent for the MET-ENK treated $(+)$ and nontreated (-) samples (Table I).

Enkephalins stimulate a naloxone-reversible enhancement in the migration of pre-B acute lymphoblastoid leukemia cells. MET-ENK was a potent stimulus for the migration of NALM 6 and LAZ 221 (pre-B ALL), but not LAZ 388 (EBV-transformed) cells (Fig. 4 and Table II). The number of NALM 6 or LAZ 221 cells which migrated to MET-ENK was greater than that which responded to the assay buffer, alone (spontaneous locomotion) $(P, \leq 0.01)$ (Fig. 4 and Table II). The effect of MET-ENK on the pre-B ALL cell migration was dose dependent (Fig. 4). MET-ENK was stimulatory over a four log dose range (0.01-100 nM); the low MET-ENK dose of $0.01 \mathrm{nM}$ resulted in a modest response which was increased with the greater $1 \mathrm{nM}$ dose and further increased with the maximum 100 nM enkephalin dose (Fig. 4).

Like MET-ENK the synthetic enkephalins DADLE and DAMGO enhanced the migration of pre-B ALL cells ( $P$, $\leq 0.01$ ); the potency of these synthetic enkephalins was near to that measured for the naturally occurring pentapeptide METENK (Table II). Unlike the enkephalins, the neutrophil chemotactic agent FMLP and the nonanalgesic peptide DesTyr-LEUENK had no effect on the migration of pre-B ALL cells ( $P$, $\mathrm{NS} \geq 0.05$ ).

The migration of LAZ 388 cells to MET-ENK, DADLE, DAMGO, DesTyr-LEU-ENK, or FMLP was equivalent to their spontaneous locomotion (response to assay buffer, alone) $(P$, NS $\geq 0.05$ ) (Table II).

Naloxone inhibited the migration of NALM 6 cells to METENK (Table III). Spontaneous locomotion resulting from ran-

Table II. The Pre-B Acute Lymphoblastoid Leukemia Cell Lines Nalm 6 and Laz 221 Migrate to Natural and Synthetic Enkephalins*

\begin{tabular}{|c|c|c|c|c|c|c|}
\hline \multirow[b]{2}{*}{ Cells } & \multicolumn{6}{|c|}{ Peptides (100 nM) } \\
\hline & $\begin{array}{l}\text { Spontaneous } \\
\text { locomotion }\end{array}$ & $\begin{array}{c}\text { FMLP } \\
\text { (nonanalgesic) }\end{array}$ & $\begin{array}{l}\text { DesTyr-LEU-ENK } \\
\text { (nonanalgesic) }\end{array}$ & MET-ENK & DAMGO & DADLE \\
\hline NALM 6 & $2190^{\ddagger}$ & $\begin{array}{c}3198 \\
(P, \mathrm{NS} ; \geq 0.05)^{8}\end{array}$ & $\begin{array}{c}3085 \\
(P, \mathrm{NS} ; \geq 0.05)\end{array}$ & $\begin{array}{r}6952 \\
(P, \leq 0.01)\end{array}$ & $\begin{array}{r}5070 \\
(P, \leq 0.01)\end{array}$ & $\begin{array}{c}6240 \\
(P, \leq 0.01)\end{array}$ \\
\hline LAZ 221 & 1886 & $\begin{array}{c}2906 \\
(P, \mathrm{NS} ; \geq 0.05)\end{array}$ & $\begin{array}{c}2010 \\
(P, \mathrm{NS} ; \geq 0.05)\end{array}$ & $\begin{array}{r}6199 \\
(P, \leq 0.01)\end{array}$ & $\begin{array}{c}4602 \\
(P, \leq 0.01)\end{array}$ & $\begin{array}{c}4405 \\
(P, \leq 0.01)\end{array}$ \\
\hline LAZ 388 & $\begin{array}{c}1938 \\
(P, \mathrm{NS} ; \geq 0.05)\end{array}$ & $\begin{array}{c}1914 \\
(P, \mathrm{NS} ; \geq 0.05)\end{array}$ & $\begin{array}{c}2244 \\
(P, \mathrm{NS} ; \geq 0.05)\end{array}$ & $\begin{array}{c}1986 \\
(P, \mathrm{NS} ; \geq 0.05)\end{array}$ & $\begin{array}{c}2043 \\
(P, \mathrm{NS} ; \geq 0.05)\end{array}$ & $\begin{array}{c}2283 \\
(P, \mathrm{NS} \\
\geq 0.05)\end{array}$ \\
\hline
\end{tabular}

* Assays were as described for Fig. $4 .{ }^{\ddagger}$ Migration was scored as described for Fig. 4 . The numbers presented are cell counts obtained by adding the values measured at $10-\mu \mathrm{m}$ intervals through the filters. ${ }^{8}$ The statistical significance of differences between the treatments was analyzed by a Dunnets multiple comparison test. 
Table III. Naloxone Inhibits the Migration of NALM 6 Cells to Methionine-Enkephalin*

\begin{tabular}{|c|c|c|c|c|c|c|}
\hline & \multicolumn{2}{|c|}{ Spontaneous locomotion } & \multicolumn{2}{|c|}{$\begin{array}{c}\text { MET-ENK } \\
(1 \mathrm{nM})\end{array}$} & \multicolumn{2}{|c|}{$\begin{array}{c}\text { MET-ENK } \\
(100 \mathrm{nM})\end{array}$} \\
\hline & Without & With $^{\ddagger}$ & Without & With & Without & With \\
\hline $\begin{array}{l}\text { Cell counts } \\
P \text { values }\end{array}$ & 1,647 & $\begin{array}{c}1,350 \\
(\mathrm{NS} ; \geq 0.05)\end{array}$ & 2,925 & $\begin{array}{l}1,251 \\
(0.01)\end{array}$ & 3,492 & $\begin{array}{l}1,476 \\
(0.01)\end{array}$ \\
\hline Percent response' & & 82 & & 43 & & 42 \\
\hline
\end{tabular}

* NALM 6 cells were cultured in RPMI 1640 medium supplemented with 2\% FBS, $100 \mu \mathrm{g} / \mathrm{ml}$ of penicillin/streptomycin, and $2 \mathrm{mM}$ glutamine or in the culture medium containing $10^{-5} \mathrm{M}$ naloxone for $15 \mathrm{~h}$ at $37^{\circ} \mathrm{C}$ in a $5 \% \mathrm{CO}_{2}$ atmosphere. Viability of the cells incubated with or without naloxone was equivalent $(\geq 96 \%)$ as judged from vital staining with trypan blue. NALM 6 cells treated with naloxone were added to the upper wells of the migration chamber in assay buffer that contained naloxone $\left(10^{-5} \mathrm{M}\right)$. Migration was allowed to proceed for $75 \mathrm{~min}$ at $37^{\circ} \mathrm{C}$. ${ }^{\ddagger}$ Without $=$ cells that were incubated in assay buffer alone; with $=$ cells that were incubated in $10^{-5} \mathrm{M}$ naloxone. Migration was scored as described for Fig. 4. The numbers presented are cell counts obtained by adding the values measured at $10-\mu \mathrm{m}$ intervals through the filters. "The statistical significance of differences between treatments was analyzed by a Student's $t$ test. 'Percent $=[($ Sum for cells incubated with naloxone $) /($ sum for cells incubated without naloxone]) $\times 100 \%$.

dom movement was equivalent for cells incubated with or without the opiate receptor antagonist $(P, \mathrm{NS}, \geq 0.05)$ (Table III).

Anti-CD 9 monoclonal antibody blocks the migration of pre$B$ acute lymphoblastoid leukemia cells to methionine-enkephalin. The migration of NALM 6 cells to MET-ENK was inhibited when the cells were preincubated with anti-CD9 $(P=0.02)$ but not anti-CD10, anti-CD29, anti-Class II or Class I mAb ( $P$, NS $\geq 0.05$ ) (Table IV). When the control cells (incubated in assay buffer, alone) or those pretreated with anti-CD10, antiCD29, anti-Class II or Class I mAb were added to the upper wells of the migration chamber the cells migrated toward METENK in the lower chamber. On the other hand, most of the cells which were pretreated with the anti-CD9 mAb remained on the surface (i.e., at the origin) with few moving down toward the enkephalin (Table IV). This effect was not due to differences in antibody isotype, since the anti-CD9 mAb that blocked migration and the anti-CD10 and -Class I mAb that were not inhibitory were of the same IgG2a isotype. Anti-CD9 induced inhibition of cell movement did not result solely from antibody induced homotypic aggregates because anti-CD29 which like anti-CD9 initiated pre-B cell homotypic aggregation (25) but had no effect on cell migration.

As indicated by the photographs of Fig. 5, cells pretreated with anti-CD9 were immobilized at the surface of the filter (Fig. 5). This immobilizing effect was not due solely to the antibodyinduced clumping since many nonclumped, single cells also remained immobilized on the topside of the filter (Fig. 5).

\section{Discussion}

Most cancer-related deaths result from the dissemination and metastasis of tumor cells; therefore, it is important to identify the signals that regulate the migration of malignant cells. In this study factors which regulate the in vitro migration of leukemia cells were identified. The naturally occurring opioid pentapeptide MET-ENK as well as the synthetic enkephalin analogs DADLE and DAMGO were shown to be stimulants for the
Table IV. Migration of NALM 6 and LAZ 221 Cells Is Inhibited by Preincubation with Anti-CD9 Monoclonal Antibody*

\begin{tabular}{|c|c|c|c|c|c|}
\hline & \multirow{3}{*}{$\begin{array}{l}\text { MET-ENK } \\
\text { (nM) }\end{array}$} & \multicolumn{4}{|c|}{ Monoclonal antibody } \\
\hline & & \multicolumn{4}{|c|}{ (Number of cells at $40 \mu \mathrm{M}$ ) } \\
\hline & & $\begin{array}{c}\text { (Buffer, } \\
\text { alone) }\end{array}$ & $\begin{array}{c}\text { anti-CD1O } \\
\operatorname{IgG2a}\end{array}$ & $\begin{array}{c}\text { anti-CD29 } \\
\operatorname{Ig} G 1\end{array}$ & $\begin{array}{c}\text { anti-CDS } \\
\operatorname{Ig} G 2 a\end{array}$ \\
\hline \multicolumn{6}{|l|}{ Experiment 1} \\
\hline \multirow[t]{5}{*}{ NALM 6 cells } & 0.0 & 135 & 160 & 175 & 94 \\
\hline & 0.01 & 238 & 354 & 406 & 92 \\
\hline & 1.0 & 407 & 510 & 629 & 77 \\
\hline & 100 & 637 & 702 & 750 & 60 \\
\hline & & $\begin{array}{l}\text { (Buffer, } \\
\text { alone) }\end{array}$ & $\begin{array}{l}\text { Class II } \\
\operatorname{IgG2b}\end{array}$ & $\begin{array}{l}\text { Class I } \\
\text { IgG2a }\end{array}$ & $\begin{array}{c}\text { anti-CD } \\
\lg G 2 a\end{array}$ \\
\hline \multicolumn{6}{|l|}{ Experiment 2} \\
\hline \multirow[t]{2}{*}{ NALM 6 cells } & 0.0 & 200 & 173 & 183 & 171 \\
\hline & 100 & 463 & 367 & 448 & 103 \\
\hline \multirow[t]{2}{*}{ LAZ 222 cells } & 0.0 & 74 & 72 & 65 & 60 \\
\hline & 100 & 280 & 231 & 324 & 92 \\
\hline
\end{tabular}

* Cells $\left(10^{7} / \mathrm{ml}\right)$ were preincubated in the migration assay buffer or the buffer containing anti-CD10, -CD29 (DE9N), or -Class II (LB 3.1), Class I (W6/32) or $-\mathrm{CD} 9 \mathrm{mAb}$ for $30 \mathrm{~min}$ at $4^{\circ} \mathrm{C}$, then pelleted by centrifugation and washed twice in assay buffer before their addition to the upper wells of the chemotaxis chamber. The mAb doses used for these studies ( $1 / 100$ dilution of ascites) were saturating as predetermined by immunofluorescent staining and flow cytometry. ${ }^{\ddagger}$ Assays were as described for Fig. 4. Cells which migrated $40 \mu \mathrm{m}$ from the origin were identified and scored visually with the use of a fluorescence microscope. The numbers presented are the cell counts determined for $10 \mathrm{high}$ power fields $\times$ triplicate wells.

migration of NALM 6 and LAZ 221 pre-B ALL cells (Fig. 4 and Table II). In a previous study (11) we showed that opioid peptides were potent signals for the migration of normal lymphocytes causing both an enhancement in their directional (chemotaxis) and random movement (chemokinesis). We found, as previously reported for the normal lymphocytes (11), that activation of the pre-B ALL cells with MET-ENK caused an increase in both their nondirectional and directional migration (data not shown). These findings identify opioid peptides as signals for the in vitro migration of cultured human leukemia cells.

The pre-B ALL cells responded to physiological doses of MET-ENK (Figs. 1 and 4). Circulating and local tissue levels of the enkephalins have been difficult to quantitate because of their rapid hydrolysis (4); however, in brain these peptides have been shown to reach concentrations of at least $0.1 \mathrm{nM}$ (32). The level measured in brain samples $(0.1 \mathrm{nM})$ is 10 times the MET-ENK dose $(0.01 \mathrm{nM})$ that induced near maximum activation of the morphological response (Fig. 1) and that caused significant increases in the pre-B ALL cell migration (Fig. 4).

It is of note that the LAZ 221 and NALM 6 pre-B ALL cells express enkephalinase (CD10; neutral endopeptidase) on their surfaces (see Fig. 2). This enzyme hydrolyzes and inactivates MET-ENK (33) and may be important in down-regulating responses to MET-ENK by either decreasing the enkephalin concentration in the surrounding medium or by degrading cellassociated MET-ENK. The migration of NALM 6 and LAZ 

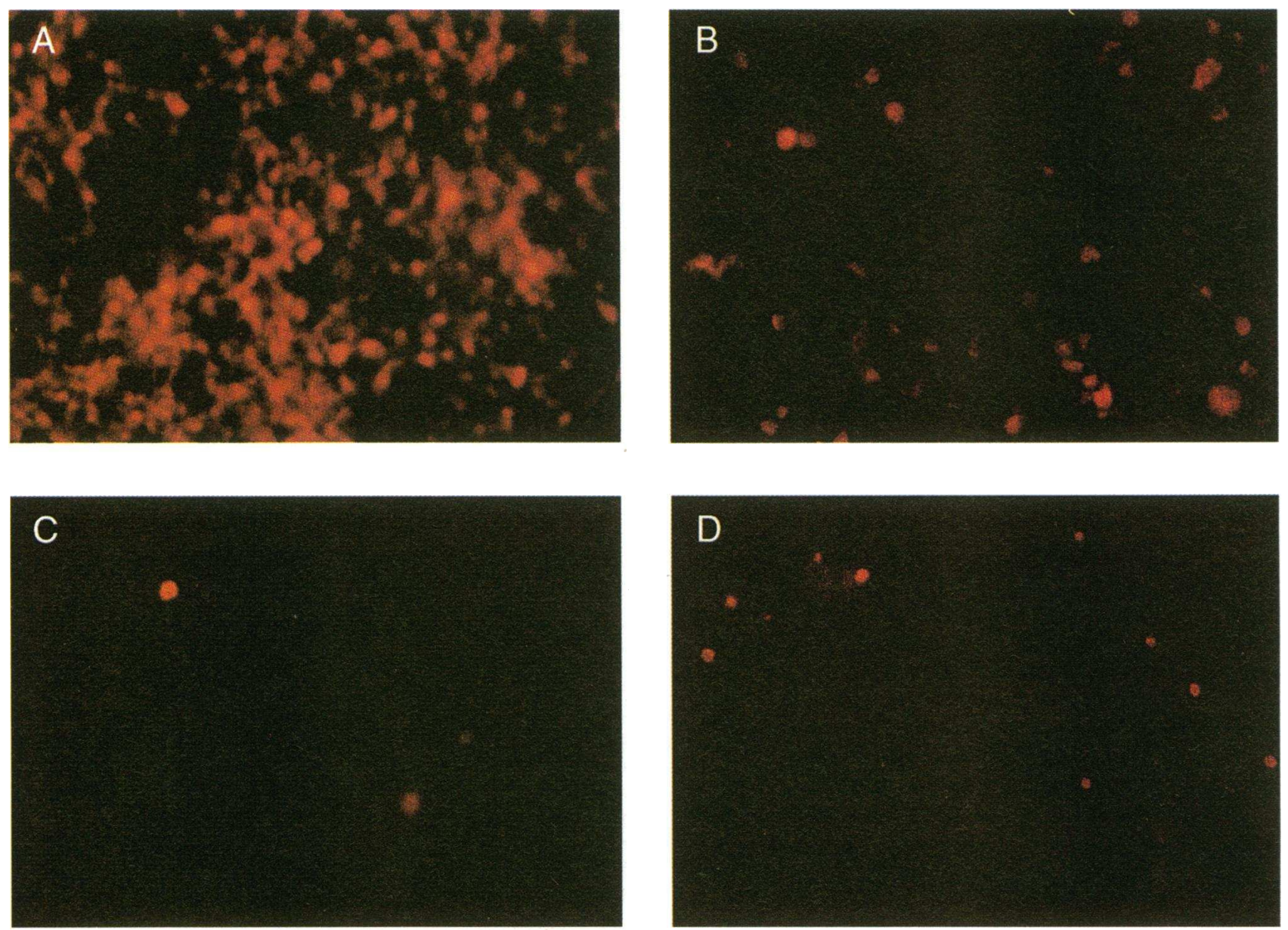

Figure 5. Anti-CD9 but not anti-CD10 monoclonal antibody blocks the migration of NALM 6 cells to methionine-enkephalin. NALM 6 cells $\left(10^{7} / \mathrm{ml}\right)$ were preincubated in the migration assay buffer containing anti-CD 9 or anti-CD10 mAb for 30 min at $4^{\circ} \mathrm{C}$. Migration assays were as described for Fig. 4 and Table II. Cells were identified for photography with the use of a fluorescence microscope $(\times 20$ objective). The cells shown in panel $A$ (at the origin, topside of filter) and panel $C$ (at 60- $\mu \mathrm{m}$ depth) depict cells preincubated with anti-CD9 mAb. The cells of panel $B$ (at the origin) and panel $D$ (at $60-\mu \mathrm{m}$ depth) were preincubated with anti-CD10 $\mathrm{mAb}$.

221 cells to MET-ENK was dose dependent; whereas the 0.01 $\mathrm{nM}$ dose stimulated a modest increase in migration, the response was increased when the dose was titered to $10 \mathrm{nM}$, and still further increased with the maximum enkephalin dose of 100 nM (Fig. 4). This dose dependency may have resulted, at least in part, from endogenous enkephalinase activity and MET-ENK hydrolysis.

In our studies we measured the effects of MET-ENK on cell morphology using flow cytometric analysis of forward and right angle light scatter (Fig. 1). In a previous report (19) the effects of opioid peptides and other chemotactic factors on the shape of granulocytes were monitored by light and electron microscopy. The opioid peptides, like other chemotactic factors, were seen to activate a morphological response before the onset of cell migration (19). This response was characterized by membrane spreading as well as cell elongation and flattening. Our studies showed that only a brief exposure $(\leq 5 \mathrm{~min})$ of the pre-B ALL cells to low doses of MET-ENK ( $0.01 \mathrm{nM})$ was sufficient to cause the morphological response (i.e., change in forward and right angle light scatter) (Fig. 1). These enkephalin effects were probably related to the spreading and flattening that cells undergo in preparation for movement. The opiate receptor antagonist naloxone inhibited the enkephalin-stimu- lated reshaping of the pre-B ALL cells (i.e., the increases in light scatter) (Fig. 1). However, when applied alone, the antagonist caused a modest deflection in the baseline light scatter (Fig. 1). The antagonist was not directly cytocidal because the viability that we measured (i.e., trypan blue exclusion) was equivalent $(\geq 96 \%)$ for naloxone-treated and nontreated NALM 6 cells. Other investigators have reported that naloxone has growth inhibitory effects on some tumor cells $(20,34)$ and the naloxone effect on light scatter that we observed may be related to such antiproliferative activity.

MET-ENK was a potent stimulant for the migration of NALM 6 and LAZ 221 pre-B ALL cells but not for the EBVtransformed, mature LAZ 388 cell line (Table II). The responsive LAZ 221 and unresponsive LAZ 388 cells have the identical genetic background since they were derived from one donor (33); however, as expected these cell lines were found to be dissimilar with respect to phenotype (Table I). The responsive LAZ 221 cells exhibited the characteristic phenotype of pre-B ALL cells (e.g., $\mathrm{CD}^{+}, \mathrm{CD}^{+} 0^{+}, \mathrm{CD}^{-} 8^{-}$) whereas the unresponsive LAZ 388 cells displayed the surface markers (e.g.,

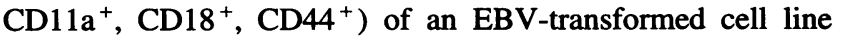
(Table I). Other investigators (9) have been unable to demonstrate the presence of classical, naloxone-sensitive MET-ENK 
receptors on EBV-transformed lymphocytes and it is likely that the LAZ 388 cells are unresponsive to MET-ENK simply because of a deficiency in enkephalin binding sites. It is known that EBV transformation renders cells unresponsive to normal activation signals (35) and it is possible, therefore, that the LAZ 388 cells are insensitive to MET-ENK by virtue of their viral transformation.

Activation of NALM 6 or LAZ 221 cells with MET-ENK correlated with an increase in migration (Fig. 4) and an enhancement in surface expression of CD9 (Figs. 2 and 3 ) but not other adhesion molecules (e.g., CD4, CD44, $\beta_{1}$, or $\beta_{2}$ integrins) (Table I). Interestingly, a similar relationship has been described by Letarte et al. (25) for pre-B ALL cell aggregations and the expression of adhesion receptors. These investigators (25) reported that the size and number of homotypic aggregates formed by various pre-B ALL cell lines correlated with the surface level of CD9, but not other adhesion molecules including CD11a, CD18, CD19, CD44, or CD54. Our studies with human pre-B ALL cells have linked CD9 expression with an important leukocyte function (migration).

The precise mechanism(s) by which $\mathrm{CD} 9$ promotes or strengthens adhesions has not, as yet, been identified. CD9 is a $24-27-\mathrm{kD}$ glycoprotein that belongs to the novel superfamily of proteins having four transmembrane domains (TM4SF) (3639). CD9 as well as some other proteins belonging to the same superfamily (i.e., TAPA-1 and M33) form multimeric complexes with other adhesion molecules (40-44) and it is possible that such multimeric complexes are important for cell adhesion and migration.

Preincubation of NALM 6 or LAZ 222 cells with anti-CD9 but not anti-CD10, anti-CD29, anti-Class I or anti-Class II mAb inhibited their migration to MET-ENK (Table IV). Miyake et al. (28) showed that the spontaneous locomotion of cultured human lung and gastric cancer cells was decreased by exposure to anti-CD9 mAb. Our findings that anti-CD9 mAb block the migration of pre-B ALL cells to MET-ENK provide the first evidence for $\mathrm{CD} 9$ involvement in the migration of any lymphoid cell. Further, they suggest that CD9 surface molecules regulate either by direct (e.g., CD9-mediated adhesions) or indirect (e.g., CD9-mediated effects on other adhesion molecules) means the leukemia cell migration to the enkephalin. Cell movement over various surfaces (e.g., membranes, culture dishes, or other cells) is accomplished via a series of coordinated attachments (adhesions) and detachments from the surface $(22,24)$. Such attachments are dependent on the expression of cell surface adhesion molecules. If CD9-mediated adhesions play a direct role in the leukemia cell migration then it is likely that the anti-CD9 mAb inhibits their migration by blocking CD9mediated cell to substrate adhesion. Previously, Ikeyama et al. (27) transfected various kinds of human and murine tumor cells with human CD9 cDNA and determined that the overexpression of surface CD9 correlated with a decrease in the spontaneous motility of the cells. If CD9-mediated adhesions play a direct role in cell motility then it may be that the overexpression of CD9 in the transfected tumor cells resulted in a strengthening of cell-to-cell and cell-to-substrate adhesions (i.e., induced cell clumping and firm attachments to the substrate) which then secondarily diminished their locomotion. On the other hand, it is plausible that CD9 regulates cell motility via indirect effects exerted on other molecules. For example, it is possible, at least in theory, that CD9 delivers transmembrane signals (45) and such signaling may render cells refractory and unresponsive to factors that stimulate cell movement (e.g., MET-ENK). If this is the case then cell exposure to anti-CD9 mAb may result in the activation of inhibitory signals (e.g., protein-tyrosine phosphorylation) and such signals may then down-regulate the cell's motility.

Exposure of NALM 6 and LAZ 221 pre-B ALL cells to MET-ENK resulted in an increase in migration and an enhancement in the surface expression of CD9. When the pre-B ALL cells were preincubated with an anti-CD9 $\mathrm{mAb}$ before challenge with the enkephalin, their migration was diminished. Our findings suggest that the cell surface expression of CD9 plays a role in the enkephalin-stimulated migration of pre-B ALL cells. These studies provide $(a)$ clues to the mechanisms by which opioid peptides modulate normal and abnormal lymphocyte functions and $(b)$ support for the notion that opioid peptides play a direct and important role in some malignant diseases.

\section{Acknowledgments}

The authors thank Mr. Leland LeCuyer for his expert assistance with graphics and photography and Ms. Edna Teng for excellent technical support.

This work was supported by the William F. Milton Fund of Harvard University (Boston, MA) and a National Institutes of Health Grant R01A129657.

\section{References}

1. Sibinga, N. E. S., and A. Goldstein. 1988. Opioid peptides and opioid receptors in cells of the immune system. Annu. Rev. Immunol. 6:219-249.

2. Manzanares, J., K. J. Lookingland, and K. E. Moore. 1990. Kappa-opioidreceptor-mediated regulation of $\alpha$-melanocyte-stimulating hormone secretion and tuberohypophyseal dopaminergic neuronal activity. Neuroendocrinology. 52:200-205.

3. Gilmore, W., M. Moloney, and L. P. Weiner. 1990. The role of opioid peptides in immunomodulation. Ann. NY Acad. Sci. 597:252-263.

4. Pasternak, G. W. 1993. Pharmacological mechanisms of opioid analgesics. Clin. Neuropharmacol. 16:1-18.

5. Stein, C., A. H. S. Hassan, K. Lehrberger, J. Giefing, and A. Yassouridis. 1993. Local analgesic effect of endogenous opioid peptides. Lancet 342:321323.

6. Peterson, P. K., T. W. Molitor, and C. C. Chao. 1993. Mechanisms of morphine-induced immunomodulation. Biochem. Pharmacol. 46:343-348.

7. Shavit, Y., G. W. Terman, F. C. Martin, J. W. Lewis, J. C. Lieberkind, and R. P. Gale. 1985. Stress, opioid peptides, the immune system, and cancer. J. Immunol. 135(Suppl.):834.

8. Chao, C. C., B. M. Sharp, C. Pomeroy, G. A. Filice, and P. K. Peterson. 1990. Lethality of morphine in mice infected with Toxoplasma gondii. J. Pharmacol. Exp. Ther. 252:605-609.

9. Borboni, P., G. D. G. Sesti, M. A. Marini, P. D. Porto, M. S. G. Montani, R. Lauro, and R. D. Pirro. 1989. $\beta$-endorphin receptors on cultured and freshly isolated lymphocytes from normal subjects. Biochem. Biophys. Res. Commun. 163:642-648.

10. Vaughn, L. K., W. S. Wire, P. Davis, Y. Shimohigashi, G. Toth, R. J. Knapp, V. J. Hruby, T. F. Burks, and H. I. Yamamura. 1990. Differentiation between rat brain and mouse vas deferens $\delta$ opioid receptors. Eur. J. Pharmacol. 177:99-101.

11. Heagy, W., M. Laurance, E. Cohen, and R. Finberg. 1990. Neurohormones regulate T cell function. J. Exp. Med. 171:1625-1633.

12. Ye, S., R. R. Applegreen, J. M. Davis, and H. T. Cheung. 1989. Modulation of lymphocyte motility by $\beta$-endorphin and met-enkephalin. Immunopharmacology. 17:81-89.

13. Ruff, M. R., and C. B. Pert. 1987. Human monocyte chemotaxis to neuropeptides. In Hypothalamic Dysfunction in Neuropsychiatric Disorders. D. Nerrozzi, F. Goodwin, and E. Costa, editors. Raven Press, Ltd., New York. 247260.

14. Saland, L. C., D. E. V. Epps, E. Ortiz, and A. Samora. 1983. Acute injections of opiate peptides into the rat cerebral ventricle: a macrophage-like cellular response. Res. Bull. 10:523-528.

15. Fischer, E. G. 1988. Opioid peptides modulate immune functions. Immunopharmacol. Immunotoxicol. 10:265-326. 
16. Moore, T. C. 1984 . Modification of lymphocyte traffic by vasoactive neurotransmitter substances. Immunology. 52:511-518.

17. Foris, G., G. A. Medgyesi, J. T. Nagy, and Z. Varga. 1987. Concentrationdependent effect of met-enkephalin on human polymorphonuclear leukocytes. Ann. NY Acad. Sci. 496:151-157.

18. Heagy, W., M. A. Shipp, and R. W. Finberg. 1992. Opioid receptor agonists and $\mathrm{Ca}^{2+}$ modulation in human $\mathrm{B}$ cell lines. J. Immunol. 149:40744081.

19. Falke, N. E., and E. G. Fischer. 1985. Cell shape of polymorphonuclear leukocytes is influenced by opioids. Immunobiology. 169:532-539.

20. Maneckjee, R., and J. D. Minna. 1992. Nonconventional opioid binding sites mediate growth inhibitory effects of methadone on human lung cancer cells. Proc. Natl. Acad. Sci. USA. 89:1169-1173.

21. Mohler, J. L., E. N. Broskie, D. J. Ranparia, Y. Sharief, W. B. Coleman and G. J. Smith. 1992. Cancer cell motility-inhibitory protein in the Dunning adenocarcinoma model. Cancer Res. 52:2349-2352.

22. Shimizu, Y., W. Newman, Y. Tanaka, and S. Shaw. 1992. Lymphocyte interactions with endothelial cells. Immunol. Today. 13:106-112.

23. Hemler, M. 1990. VLA proteins in the integrin family: structures, functions, and their role in leukocytes. Annu. Rev. Immunol. 8:365-400.

24. Springer, T. A. 1990. Adhesion receptors of the immune system. Nature (Lond.). 346:425-433.

25. Letarte, M., J. G. Seehafer, A. Greaver, A. Masellis-Smith, and A. R. E. Shaw. 1993. Homotypic aggregation of pre-B leukemic cell lines by antibodies to VLA integrins correlates with their expression. Leukemia (Baltimore). 7:93103.

26. Masellis-Smith, A. 1990. Anti-CD9 monoclonal antibodies induce homotypic adhesion of pre-B cell lines by a novel mechanism. J. Immunol. 144:16071613.

27. Ikeyama, S., M. Koyama, M. Yamaoko, R. Sasada, and M. Miyake. 1993. Suppression of cell motility and metastasis by transfection with human motilityrelated protein (MRP-1/CD9) DNA. J. Exp. Med. 177:1231-1237.

28. Miyake, M., M. Koyama, M. Seno, and S. Ikeyama. 1991. Identification of the motility-related protein (MRP-1), recognized by monoclonal antibody M31-15, which inhibits cell motility. J. Exp. Med. 174:1347-1354.

29. Shipp, M. A., J. Vijayaraghavan, E. V. Schmidt, E. L. Masteller, L. D'Adamio, L. B. Hersh, and E. L. Tempel. 1989. Common acute lymphoblastic leukemia antigen (CALLA) is active neutral endopeptidase 24.11 ("enkephalinase"): direct evidence by cDNA transfection analysis. Proc. Natl. Acad. Sci. USA. 86:297-301.

30. Bergelson, J. M., M. P. Shepley, B. M. C. Chan, M. E. Hemler, and R. W. Finberg. 1992. Identification of the integrin VLA-2 as a receptor for Echovirus1. Science (Wash. DC). 255:1718-1720.

31. Sklar, L. A., Z. G. Oades, and D. A. Finney. 1984. Neutrophil degranulation detected by right angle light scattering: spectroscopic methods suitable for simultaneous analyses of degranulation or shape change, elastase release, and cel aggregation. J. Immunol. 133:1483-1487.

32. Wardlaw, S. L., W. B. Wehrenberg, M. Ferin, P. W. Carmel, and A. G.
Frantz. 1980. High levels of $\beta$-endorphin in hypophyseal portal blood. Endocrinology. 106:1323-1326.

33. Shipp, M. A., G. B. Stefano, L. D'Adamio, S. N. Swetzer, F. D. Howard, J. Sinisterra, B. Scharrer, and E. L. Reinherz. 1990. Down regulation of enkephalinmediated inflammatory responses by CD10/neutral endopeptidase 24.11. Nature (Lond.). 347:394-396

34. Zagon, I. S., and P. J. McLaughlin. 1987. Modulation of murine neuroblastoma in nude mice by opioid antagonists. J. Natl. Cancer Inst. 78:141-147.

35. Nilsson, K., and G. Klein. 1982. Phenotypic and cytogenetic characteristics of human B-lymphoid cell lines and their relevance for the etiology of Burkitt's lymphoma. Adv. Cancer Res. 37:319-380.

36. Rubinstein, E., P. Benoit, M. Billard, S. Plaisance, M. Prenant, G. Uzan and C. Boucheix. 1993. Organization of the human CD9 gene. Genomics. 16:132138.

37. Ebener, U., S. Wehner, J. Cinatl, E. S. Gussetis, and B. Kornhuber. 1990. Expression of markers shared between human haematopoietic cells and neuroblastoma cells. Anticancer Res. 10:887-890.

38. Komada, Y., H. Ochiai, K. Shimizu, E. Azuma, H. Kamiya, and M Sakurai. 1992. Shedding of CD9 antigen into cerebrospinal fluid by acute lymphoblastic leukemia cells. Blood. 76:112-116.

39. Zola, H., V. Furness, S. Barclay, H. Zowtyj, M. Smith, J. V. Melo, S. H Neoh, and J. Bradley. 1989. The p24 leucocyte membrane antigen: modulation associated with lymphocyte activation and differentiation. Immunol. Cell Biol. 67:63-70.

40. Imai, T., and O. Yoshie. 1993. C33 antigen and M38 antigen recognized by monoclonal antibodies inhibitory to syncytium formation by human $\mathrm{T}$ cell leukemia virus type 1 are both members of the transmembrane 4 superfamily and associate with each other and with CD4 or CD8 in T cells. J. Immunol. 151:64706481

41. Seehafer, J. G., and A. R. Shaw. 1991. Evidence that the signal-initiating membrane protein CD9 is associated with small GTP-binding proteins. Biochem. Biophys. Res. Commun. 179:401-406.

42. Slupsky, J. R., J. G. Seehafer, S. C. Tang, A. Masellis-Smith, and A. R. E. Shaw. 1989. Evidence that monoclonal antibodies against CD9 antigen induce specific association between CD9 and the platelet glycoprotein IIb-IIIa complex. J. Biol. Chem. 264:12289-12293.

43. Mitamura, T., R. Iwamoto, T. Umata, T. Yomo, I. Urabe, and M. Tsuneoka. 1992. The 27-kD diphtheria toxin receptor-associated protein (DRAP27) from Vero cells is the monkey homologue of human CD9 antigen: expression of DRAP27 elevates the number of diphtheria toxin receptors on toxin-sensitive cells. J. Cell Biol. 1992:1389-1399.

44. Bradbury, L. E., V. S. Goldmacher, and T. F. Tedder. 1993. The CD19 signal transduction complex of B lymphocytes: deletion of the CD19 cytoplasmic domain alters signal transduction but not complex formation with TAPA-1 and Leu 13. J. Immunol. 151:2915-2927.

45. Yatomi, Y., Y. Ozaki, K. Satoh, and S. Kume. 1993. Anti-CD9 monoclonal antibody elicits staurosporine inhibitable phosphatidylinositol 4,5-bisphosphate hydrolysis, phosphatidylinosital 3,4-bisphosphate synthesis, and protein-tyrosine phosphorylation in human platelets. FEBS Lett. 322:285-290. 